\title{
DAYA DUKUNG HIJAUAN DAN LIMBAH TANAMAN PANGAN PENGEMBANGAN POPULASI TERNAK SAPI POTONG DI KECAMATAN TOMPASO KABUPATEN MINAHASA
}

\author{
Erwin Wantasen, S Dalie dan F.N.S. Oroh \\ Fakultas Peternakan Universitas Sam Ratulangi \\ Email : erwinwantasen@yahoo.co.id
}

\begin{abstract}
ABSTRAK
Pengembangan peternakan saat ini menunjukan adanya prospek yang sangat cerah dan mempunyai peranan penting dalam pertumbuhan ekonomi pertanian. Permasalahannya sejauh mana daya dukung lahan sebagai sumber pakan ternak Berdasarkan permasalahan ini maka dilakukan penelitian dengan tujuan untuk mengetahui daya dukung pengembangan ternak sapi di Kecamatan Tompaso Kabupaten Minahasa . Penelitian ini dilakukan dengan menggunakan metode analisa data sekunder dimana data yang dianalisis diperoleh dari kantor Kecamatan dan Kantor BP3K (Balai penyuluhan, pertanian, perikanan dan kehutanan) Kecamatan Tompaso Kabupaten Minahasa antara lain data luas dan penggunaan lahan pertanian, perkebunan, kehutanan dan populasi ternak sapi. Model analisis yang digunakan yaitu analisis deskriptif, dan analisis potensi pengembangan ternak efektif. Hasil penelitian menunjukan produksi hijauan efektif di Kecamatan Tompaso sebesar 1.811,86 ton/tahun, produksi jerami efektif sebesar 6.630,39 ton/tahun. Kapasitas tampung maksimum dalam satuan ternak berdasarkan sumberdaya lahan sebesar 4.020,11 ST dan kapasitas peningkatan populasi ternak ruminansia (sapi) berdasarkan sumberdaya lahan (KPPTR) sebesar 1.459,65 ST, Berdasarkan hasil penelitian dapat disimpulkan bahwa wilayah Kecamatan Tompaso potensial untuk pengembangan ternak sapi.
\end{abstract}

Kata kunci : ternak sapi, daya dukung, hijauan, limbah tanaman pangan

\begin{abstract}
Farm development showed a good prospect and has an important role in the growth of the agricultural economy . The problem is how far the supported of land resources, can increase the cattle population in Tompaso district of Minahasa regency.. Based on this problems the study was applied. The aimed of the research was to know potensial development of cattle in Tompaso sub district Minahasa regency based on the availability of forages and agriculture by product. Secondary data analysis methods was used to meet the objectif of the research such as planted area used by the farmers and population of cattle in Tompaso sub district. The data was collected from extension office of agriculture, fisheries and forestry $\left(\mathrm{BP}_{3} \mathrm{~K}\right)$ and agriculture service of Minahasa regency. Potensial livestock development analysis was used to find out the goal of the research. Result of this study showed the effectif forages production were 1.811,86 ton p.a. Effectif production of agriculture by product was $6.630,39$ ton p.a.. Maximum carrying capacity of Tompaso sub district were 4.020,11 animal unit. Capacity increase of cattle population by land resources ( KPPTR) were 1.459,65 animal unit. Based on the research, Tompaso sub district has carrying capacity as developing area of cattle in Minahasa Regency North Sulawesi.
\end{abstract}

Keywords : cattle, carrying capacity, forages, agriculture by product

\section{PENDAHULUAN}

Untuk memperoleh ternak yang memiliki kualitas baik diperlukan ketersediaan pakan yang memadai. Mutu dan ketersediaan pakan dalam bentuk hijauan maupun pakan konsentrat yang mencukupi dan berkelanjutan (kontinyu) sangat penting dalam menjaga kestabilan usaha pengembangan ternak ruminansia termasuk sapi potong yang tergabung dalam wadah kelompok maupun usaha ternak skala kecil. Ketersediaan pakan secara kontinyu (hijauan dan konsentrat), yang sesuai standar dalam usaha sapi potong disepanjang waktu akan memberikan kemantapan dalam usaha dan nilai keuntungan yang lebih baik bagi peternak. Disamping itu diketahuinya daya tampung HMT bagi ternak akan menjamin kepastian berusaha dan keuntungan ekonomi yang dapat diperoleh peternak (Thahar dkk., 1991; Puji 
2006; Hidayat dkk., 2006).

Menurunnya daya dukung sumberdaya alam (pakan) untuk usaha ternak karena konversi lahan pertanian, serta perubahan pola budidaya menjadi salah satu penyebab menurunnya populasi ternak. Sementara itu subsektor peternakan diharapkan mampu memenuhi permintaan akan protein hewani yang semakin meningkat, meningkatnya penyerapan tenaga kerja dan PDRB, ini berarti menuntut subsektor peternakan untuk dapat memacu produksinya (baik kuantitas maupun kualitas). Sementara disisi lain, sub-sektor peternakan dihadapkan kepada semakin menyempitnya lahan usaha akibat persaingan yang semakin meningkat baik antar sektor maupun antar sub-sektor dalam penggunaan lahan. Oleh karena itu potensi hijuan dan limbah tanaman pangan menjadi alternatif untuk memenuhi kebutuhan pakan ternak ruminansia seperti ternak sapi potong sekaligus menciptakan usaha ternak ruminansia dalam pembangunan agribisnis yang berwawasan lingkungan ( Suryanto, 2004 ; Febrina dan Liana, 2008 ; Alfian dkk., 2012 )

Beberapa upaya untuk meningkatkan produktivitas ternak, pengembangan usaha ternak ruminansia sekaligus pendapatan petani adalah mengatahui faktor sosial, ekonomi dan demografi peternak, wilayah basis ternak, daya dukung lahan dan ketersediaan pakan ternak, melalui pewilayahan komoditi ternak dan integrasi tanaman dan ternak (Kreuter dan Workman, 1994; Djaenudin dkk.., 2002; Tanuwiria dkk.., 2006; Suyitman dkk.., 2009; Alfian dkk.., 2012; Hartono, 2012; Nugraha dkk.., 2013). Karena itu untuk menunjang peningkatan ekonomi wilayah Kecamatan Tompaso Kabupaten Minahasa maka pengembangan usaha ternak sapi harus ditunjang oleh kondisi sumberdaya alam seperti ketersediaan pakan hijauan dan pakan dari limbah tanaman pangan. Hal ini mengingat potensi ternak sapi yang dimilik wilayah Kecamatan Tompaso Kabupaten Minahasa cukup menjanjikan dimana pada tahun 2013 jumlah populasi ternak sapi yang tersedia adalah 2753 ekor yang terdiri atas 791 ekor sapi jantan dan 1962 ekor sapi betina ( BPS Sulut, 2014). Permasalahannya adalah sejauh mana ketersediaan hijauan makanan ternak dan limbah tanaman pangan dapat mendukung upaya pengembangan ternak sapi yang menjadi salah satu tulang punggung ekonomi keluarga petani di wilayah Kecamatan Tompaso Kabupaten Minahasa.

\section{METODE PENELITIAN}

Penelitian ini dilaksanakan di Kecamatan Tompaso Kabupaten Minahasa Propinsi Sulawesi Utara . Pengumpulan data dilakukan pada bulan Maret 2015, dengan menggunakan metode analisis data sekunder yaitu menganalisa lebih lanjut data yang sudah tersedia untuk mencapai tujuan penelitian ( Singarimbun dan Effendi, 1986). Data diperoleh dari Badan Penyuluhan pertanian, perikanan dan kehutanan (BP3K) Kecamatan Tompaso, Dinas Pertanian dan Peternakan Kabupaten Minahasa dan Dinas Kehutanan dan Perkebunan Kabupaten Minahasa serta Kantor Statistik Kabupaten Minahasa. Data yang dikumpulkan meliputi data populas ternak sapi, tata guna lahan, luas lahan, luas panen, produksi dan produktivitas tanaman pangan dan tanaman perkebunana, data iklim dan topografi.

Analisis data menggunakan metode analisis potensi ketersediaan pakan berupa hijauan pakan dan limbah tanaman pangan efektif untuk mengetahui kapasitas daya tampung ternak di wilayah penelitian (Nell dan Rollinson, 1974 dalam Tanuwirya dkk., 2006)

\section{HASIL DAN PEMBAHASAN}

Luas wilayah Kecamatan Tompaso 10.398 $\mathrm{Km}^{2}$ yang diklasifikasikan menurut ekosistem dan penggunaannya, sebagai berikut: Lahan kering 5533 ha yang terdiri dari lahan perkebunan 1087 ha, tegalan 1657 ha dan hutan 2789 ha. Lahan rawa 677 ha yang terdiri dari lahan sawah 498 ha dan kolam 79 ha dan padang rumput 293 ha . Data hasil penelitian menujukkan bahwa lahan kering merupakan penggunaan lahan terbesar sedangkan penggunaan lahan terkecil adalah padang rumput (BPS , Kabupaten Minahasa 2014). Sumberdaya pertanian yang terdapat di Kecamatan Tompaso Kabupaten Minahasa yaitu padi sawah, padi ladang, jagung, ubi kayu, ubi jalar, kacang tanah, kacang hijau, kacang merah, kacang panjang, kedelai, bawang merah, dan daun bawang. Luas tanam keseluruhannya berjumlah 1.956 ha dan luas panen keseluruhan berjumlah 1.708 ton. Sumberdaya perkebunan terdiri dari kelapa, vanili, kopi, Aren, dan Cassiavera. Luas areal keseluruhannya berjumlah 1087 ha dan produksi keseluruhan 697,5 ton (Dinas Pertanian dan Peternakan Kabupaten Minahasa 2014; Dinas Kehutanan dan Perkebunan Kabupaten Minahasa 2014).

Jumlah populasi ternak sapi di wilayah Kecamatan Tompaso dalam satuan ternak adalah 2560,46 ST dimana usaha ternak sapi masih merupakan usaha sampingan dengan kepemilikan 1-2 ST per kepala keluarga padahal luas lahan dan potensi pakan hijauan dan limbah pertanian cukup besar. Hasil analisis potensi maksimum sumber daya lahan di Kecamatan Tompaso dapat dilihat pada Tabel 1

Hasil analisis kapasitas peningkatan populasi ternak sapi berdasarkan Sumberdaya lahan KPPTR dilihat padaTabel 2. Data Tabel 2 menunjukkan kapasitas peningkatan populasi ternak sapi berdasarkan 
Tabel 1. Hasil analisis PMSL Kecamatan Tompaso Kabupaten Minahasa

\begin{tabular}{|c|c|c|}
\hline No. & Koefisien/Variabel & KecamataTompaso \\
\hline 1 & a & 0,7 \\
\hline 2 & LKrg & 5533 \\
\hline 3 & $b$ & 0,8 \\
\hline 4 & PDG & 307 \\
\hline 5 & c & 1,8 \\
\hline 6 & $\mathrm{R}$ & 435 \\
\hline 7 & KTM & 4020,11 \\
\hline \multicolumn{3}{|c|}{ Sumber : Data diolah (2015) } \\
\hline \multicolumn{3}{|c|}{ Keterangan } \\
\hline KTM : & \multicolumn{2}{|c|}{$\begin{array}{l}\text { Kapasitas Tampung Maksimum dalam satuan ternak sapi (ST) berdasarkan } \\
\text { sumberdaya, yaitu sapi dewasa }=1,00 \mathrm{ST} / \mathrm{Ha} \text {, sapi muda }=0,75 \mathrm{ST} / \mathrm{Ha} \text { dan } \\
\text { sapi anak }=0,25 \mathrm{ST} / \mathrm{Ha} \\
\text { Koefisien yang dihitung berdasarkan ratio populasi ternak ruminansia dalam }\end{array}$} \\
\hline A & \multicolumn{2}{|c|}{$\begin{array}{l}\text { Koefisien yang dihitung berdasarkan ratio populasi ternak ruminansia dalam } \\
\text { satuan ternak (ST) dengan luas lahan garapan atau lahan kering adalah } 0,7\end{array}$} \\
\hline LKrg & \multicolumn{2}{|c|}{$\begin{array}{l}\text { ST/Ha } \\
\text { Luas lahan kering di Kecamatan Tompaso (Ha) }\end{array}$} \\
\hline b & \multicolumn{2}{|c|}{$\begin{array}{l}\text { Koefisien yang dihitung sebagai kapasitas tampung padang rumput alam } \\
=0,8 \mathrm{ST} / \mathrm{Ha} \mathrm{PDG}=\text { Luas padang rumput }(\mathrm{Ha})\end{array}$} \\
\hline c & \multicolumn{2}{|c|}{$\begin{array}{l}\text { Koefisien yang dihitung sebagai kapasitas tampung rawa }(1,8 \mathrm{ST} / \mathrm{Ha}) \mathrm{R} \\
=\text { Luas Rawa }\end{array}$} \\
\hline
\end{tabular}

sumberdaya lahan di Kecamatan Tompaso sebanyak 1459,65 ST. Artinya untuk memenuhi kapasitas tampung maksimum lahan maka populasi ternak sapi di Kecamatan Tompaso masih dapat ditingkatkan sebanyak 1459,65 ST. Tingkat ketersediaan hijauan makanan ternak pada suatu wilayah merupakan salah satu faktor yang sangat penting dalam meningkatkan populasi dalam keberhasilan pengembangan ternak khususnya ternak sapi.

Tabel 2. Hasil Analisis KPPTR Kecamatan Tompaso Kabupaten Minahasa

\begin{tabular}{ccc}
\hline No. & Koefisien/Variabel & Satuan Ternak (ST) \\
\hline 1 & KTM & 4020,11 \\
2 & POP & 2560,46 \\
3 & KPPTR & 1459,65 \\
\hline
\end{tabular}

Sumber. Data dioleh (2015).

Keterangan:

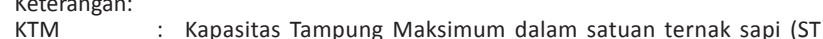
berdasarkan sumberdaya, yaitu sapi dewasa $=1,00 \mathrm{ST} / \mathrm{Ha}$, sapi muda $=0,75 \mathrm{ST} / \mathrm{Ha}$ dan sapi anak $=0,25$

ST/Ha KPPTR : Kapasitas peningkatan populasi ternak sapi (ST) berdasarkan POP $\quad$ : Pumberdaya lahan

Kapasitas tampung ternak ruminansia di Kecamatan Tompaso Kabupaten Minahasa sangat dipengaruhi oleh ketersediaan tanaman hijauan sebagai pakan ternak. Wilayah Kecamatan Tompaso memiliki potensi ketersediaan pakan hijauan dan limbah berupa jerami tanaman pangan untuk ternak ruminansia (sapi dan kambing) dan ternak non ruminansia ( ayam, dan itik) Produksi hijauan dan produksi jerami efektif per tahun di Kecamatan Tompaso disajikan pada Tabel 3 .

Hasil penelitian pada Tabel 3 menunjukkan bahwa Kecamatan Tompaso memiliki jumlah produksi hijauan efektif dari berbagai sumber lahan seperti padang rumput, sawah, lading, hutan dan tanah perkebunan dengan jumlah produksi 1811,86
Tabel 3. Produksi Hijauan dan jerami secara efektif di Kecamatan Tompaso

\begin{tabular}{|c|c|c|c|c|}
\hline No. & $\begin{array}{c}\text { Sumber hijauan } \\
\text { pakan }(\mathrm{Ha})\end{array}$ & $\begin{array}{l}\text { Produksi Hijauan } \\
\text { (Ton/Tahun) }\end{array}$ & $\begin{array}{c}\text { Sumber pakan } \\
\text { jerami }\end{array}$ & $\begin{array}{l}\text { Produksi Jerami } \\
\text { (Ton/tahun) }\end{array}$ \\
\hline 1. & Padang rumput & 208,18 & Jerami padi & 299,69 \\
\hline 2 & Sawah & 25,03 & Jerami jagung & 6005,9 \\
\hline 3 & Ladang/tegalan & 19,78 & Jerami ubi kayu & 146,45 \\
\hline 4 & Hutan & 1.348 & Jerami kedelai & 138,03 \\
\hline 5 & Perkebunan & 210,4 & $\begin{array}{l}\text { Jerami kacang } \\
\text { tanah }\end{array}$ & 40,32 \\
\hline & Jumlah & 1811,86 & Jumlah & $6.630,39$ \\
\hline
\end{tabular}

Sumber : Data diolah, 2015

ton/tahun dan produksi limbah berupa jerami pakan sebesar 6630,39 ton/tahun. Melalui potensi produksi jerami dari tanaman pangan maka akan bermanfaat untuk penyediaan pakan ternak sapi disaat kekurangan pasokan makanan ternak seperti saat musim kemarau melalui pemanfaatan teknologi pengawetan seperti penyimpanan, pengawetan dan peningkatan nilai nutrisi agar sapi sapi yang dihasilkan akan memiliki nilai ekonomi yang tinggi bagi keluarga petani (Zulbardi dkk., 2001).

\section{KESIMPULAN}

Berdasarkan hasil penelitian dapat disimpulkan bahwa Kecamatan Tompaso Kabupaten Minahasa mempunyai potensi daya dukung yang sangat besar dalam meningkatkan populasi ternak sapi dilihat dari sumberdaya lahan yang tersedia, dan penyediaan makanan ternak.

\section{DAFTAR PUSTAKA}

Alfian, Y., F. I. Hermansyah, E. Handayanta, Lutojo, dan W. P. S. Suprayogi. 2012. Analisis Daya Tampung Ternak Ruminansia pada Musim Kemarau di Daerah Pertanian Lahan Kering Kecamatan Semin Kabupaten Gunungkidul . Trop. Anim. Husbandry 1 (1):33-42

BPS Kabupaten Minahasa. 2014. Kabupaten Minahasa Dalam Angka 2014. Kantor Statistik Kabupaten Minahasa, Tondano.

Dinas Pertanian dan Peternakan Kabupaten Minahasa. 2014. Luas Lahan, Luas Panen, Produksi dan Produktivitas Tanaman Pangan Menurut Kecamatan di Kabupaten Minahasa. Laporan Tahunan, Tondano.

Dinas Kehutanan dan Perkebunan Kabupaten Minahasa. 2014. Luas Lahan, Luas Panen, Produksi TYanaman Perkebunan Menurut Kecamatan. Laporan Tahunan, Tondano

Djaenudin D., Y Sulaeman dan A. Abdurachman. 2002. Pendekatan Pewilayahan Pertanian Menurut 
Pedro -Agroklimat di Kawasan Timur Indonesia. J. Litbang Pertanian 21 (1) : 1-10

Febrina, D. dan M. Liana. 2008. Pemanfaatan Limbah Pertanian Sebagai Pakan Ruminansia pada Peternak Rakyat di Kecamatan Rengat Barat Kabupaten Indragiri Hulu. J.Peternakan. 5 (1) : $28-37$.

Hartono. B. 2012. Peran Daya Dukung Wilayah Terhadap Pengembangan Usaha Peternakan Sapi Madura. J. Ekonomi Pembangunan 13 (2) :316-326

Hidayat, U.T., A Yulianti dan N Mayasari 2006. Potensi pakan asal lombah tanaman pangan dan daya dukungnya tetrhadap populasi ternak ruminansia di wilayah Sumedang. J ilmu ternak 6 (2): 112-120

Kreuter, U.P dan J.P Workman. 1994. Costs of Overstocking on Cattle and Wildlife Ranches in Zimbabwe. Ecological Economics 11 : 237-248

Nugraha. B.D., E. Handayanta dan E.T. Rahayu. 2013. Analisis Daya Tampung Ternak Ruminansia Pada Musim Penghujan di Daerah Pertanian Lahan Kering Kecamatan Semin Kabupaten Gunung Kidul. Trop. Anim. Husbandry 2 (1): 34-40

Puji F. A. 2006 Arahan Pewilayahan Komoditas Unggulan DI Kabupaten Kotawaringin Timur Thesis.PPs Magister pembangunan wilayah dan kota UNDIP Semarang.

Suryanto, B. 2004. Peran Usahatani Ternak Ruminansia dalam Pembangunan Agribisnis Berwawasan
Lingkungan. Pidato pengukuhan: Upacara Peresmian Penerimaan Jabatan Guru Besar dalam Ilmu Manajemen Usahatani. Fakultas Peternakan Universitas Diponegoro. Semarang. Suyitman, Surjono, H.S., C. Herison dan Muladno. 2009. Status Keberlanjutan Wilayah Berbasis Peternakan di kabupaten Situbondo untuk Pengembangan Kawasan Agropolitan. Jurnal Agro Ekonomi. 27 (2): 165-191.

Tanuwirya, A. U., A Yulianti dan Mayaari. 2006. Potensi Pakan Asal Limbah Tanaman Pangan dan Daya Dukungnya Terhadap Populasi Ternak Ruminansia di Wilayah Sumedang. J. Ilmu Ternak 6(2) : 112-120

Thahar, A., Santoso, Sumanto, Hatomo dan Haryono. 1991 Daya Dukung Pakan Karang Agung Sungai Lilin, Sumatera Selatan. Makalah Kerja No. 3 Proyek Ternak Kerja. Balai Penelitian Ternak, Badan Litbang Pertanian. Disiapkan untuk Temu Lapang Departemen Pertanian, 7 Maret 1991 di Karang Agung Kabupaten Musibanyuasin, Sumatera Selatan

Zulbardi, M., A. A. Karto, U. Kusnadi dan A. Thalib. 2001. Pemanfaatan Jerami Padi Bagi Usaha Pemeliharaan Sapi Peranakan Onggole di Daerah Irigasi Tanaman Padi. Dalam: Prosiding Seminar Nasional Teknologi Peternakan dan Veteriner. Puslitbang Peternakan Departemen Pertanian. Bogor. Hal. 256- 26 